\section{ÜGYFÉLÉLMÉNY AZ ÜGYFELEK SZERINT: FELTÁRÓ KUTATÁS A BIZTOSÍTÁSI PIACON}

Stefkovics Ádám (a Századvég Alapitvány munkatársa, igazgatóhelyettes, doktorandusz az ELTE Társadalomtudományi Karán), stefkovics@szazadveg.hu

\section{ÖSSZEFOGLALÓ}

A jövőben azok a szereplők lesznek képesek versenyelőnyre szert tenni a piacon, akik megértik ügyfeleik élményeit, érzéseit. De vajon értjük-e ügyfeleinket? Jelen tanulmány arra a kérdésre keresi a választ, hogy mit jelent ma Magyarországon a biztosítók ügyfelei számára az ügyfélélmény. A tanulmány egy komplex módszertanú közvélemény-kutatás eredményeire épít. Az eredmények alapján az ügyfelek elégedettsége magas, ám az elköteleződés relatíve alacsony (NPS=+4,6). A legfontosabb ügyfélélmény-elemek a megbízhatóság, a segítőkész dolgozók, az érthető kommunikáció, a gyors, könnyü ügyintézés, a jó minőségű szolgáltatás és az ügyfelek igényeinek megértése. Jóval kevésbé hatnak az elégedettségre a digitális szolgáltatások vagy a személyre szabott szolgáltatások. Az alacsony elköteleződés a biztosító és ügyfél közötti interakciók, élmények alacsony számára és a személytelenségre vezethető vissza, így ezek javítása kulcskérdés. További javaslat a lojalitás erősítése és az ügyfelek edukálása az innovatív és digitális megoldások terén.

\section{SUMMARY}

Monitoring and improving customer experience has become a fundamental strategic goal in business. Those operators who can understand its customers' experiences and feelings will gain advantage. But do we understand our customers? This study investigates what does customer experience mean for the customers of insurance companies nowadays in Hungary. The analysis is based on a poll conducted with complex methodology. The results suggests that satisfaction is high among customers, while engagement is relatively low (NPS=+4,6). The most important elements of customer experience is reliability, helpful workers, understandable communication, fast and easy administration, high quality service and understanding customer's needs. Satisfaction is less affected by digital services or tailored services. Low engagement is likely to be correlated with the low amount of interaction and experience between the company and its customer, as well as with impersonality, therefore improving these is a key issue. Improving loyalty and educating customers about digital and innovative solutions are also advised.

Kulcsszavak: ügyfélélmény, elégedettség, elköteleződés, biztosítás Key words: customer experience, satisfaction, engagement, insurance
JEL: D12, M31, G22, G52

DOI: $10.18530 /$ BK.2019.4.28

http://dx.doi.org/10.18530/BK.2019.4.28

\section{Bevezetés}

„Azért mi is van, hogy olyan dolgokat akarunk kisajtolni a biztositóból, ami nem jogos.” - relativizálja a biztosító-biztosítotti viszonyt egy fókuszcsoport résztvevője a Századvég által, a MABISZ megrendelésére készült, ügyfélélmény-fókuszú kutatásban. Az ügyfélélmény (CX) monitorozása és javítása mára alapvetésnek számít az üzleti életben. A Walker (2013) által készített nemzetközi kutatás szerint a vállalatvezetők az ügyfélélményt azonosítják a leghatékonyabb eszközként, amelyből versenyelőnyük származhat, Magyarországon pedig már 2016-ban a vállalatvezetők 75 százaléka a három legfontosabb stratégiai cél egyikeként kezelte (Develor, 2016). Egyre gyakrabban találkozhatunk a nagyobb vállalatoknál olyan pozíciókkal, mint $C X$ Officer, $C X$ Vice President, $C X$ Manager stb. (Lemon - Verhoef, 2016).

De mit is értünk pontosan ügyfélélmény alatt, és miért ennyire fontos? Nagyon nehéz definiálni a fogalmat, mindenki mást ért alatta, mindenki másra és másként használja. Az ügyfélélmény lényege mégis abban ragadható meg, hogy nem magára a szolgáltatásra, a termékre fókuszál, hanem arra, ahogy a vásárló a folyamatokat és kapcsolódásokat értelmezi, megéli (Johnston - Kong, 2011). Az ügyfélélmény a márka és a vásárló közötti kapcsolódások érzelmi lenyomata. Fontos körülmény, hogy a cégek nem kontrollálják az összes interakciót, és az egyéni reakciók is csak részben tudatosak (Lemon - Verhoef, 2016).

Az elmúlt évtized tanulsága az, hogy azok a szereplők lesznek képesek versenyelőnyre szert tenni, akik képesek stratégiájukat a fogyasztóik élményeinek megértésére és javítására építeni.

Az ügyfélélmény-központú stratégiaalkotás népszerűségének növekedése arra vezethető vissza, hogy az ügyfelek ma már jóval összetettebb és töredezettebb szociális és médiatérben mozognak. Ebből az következik, hogy a cégek jóval kevésbé képesek kontrollálni a márka és a fogyasztó között kapcsolódási pontokat és élményeket. A korábban bevált módszerek (customer service) ma már nem alkalmasak az ügyfélút megértésére (Lemon - Verhoef, 2016). Az elmúlt évtized tanulsága az, hogy azok a szereplők lesznek képesek versenyelőnyre szert tenni, akik képesek stratégiájukat a fogyasztóik élményeinek megértésére és javítására építeni. 
Nincs ez másként a biztosítótársaságoknál sem. A Capgemini (2019) jelentése strukturális átalakulást vetít előre a biztosítótársaságoknak. Ennek egyik lényegi eleme a fogyasztói igények holisztikus kezelése, különös fókusszal a digitális szolgáltatásokra. A hazai biztosítási szakma is felismerte az ügyfélélmény monitorozásának jelentőségét ${ }^{1}$, több kutatás is készült a témában. A Develor által 2013-ban folytatott Országos Ügyfélélmény Kutatások egyik fö tanulsága, hogy a hazai vállalatok ügyfélélmény-fejlesztési törekvéseinek - lassan ugyan és nem minden szektorban, de - kezd látszani a hatása. Az NPS-értékek (Net Promoter Score, Nettó Ajánlási Érték ${ }^{2}$ ) a legtöbb ágazatban emelkednek, köztük a biztosítószektornál is. A biztosítási szakma számára szintén pozitív hír, hogy a KPMG (2018) hazai felmérése alapján az ötven legjobb ügyfélélményt nyújtó magyarországi márka közé három biztosító is bekerült (K\&H, Allianz és Aegon). A Develor kutatói úgy látják, a fogyasztók igényei is folyamatosan változnak, és az elvárásaik is nőttek a szolgáltatókkal szemben. ${ }^{3}$ Hogy pontosan mik az elvárásaik, és mit jelent a fogyasztóknak a jó ügyfélélmény, az továbbra sem teljesen világos, különösen annak fényében, hogy ezek az elvárások vélhetőleg ágazatspecifikusak.

Jelen tanulmány a Századvég Alapítvány által 2019-ben, a MABISZ megrendelésére készített komplex módszertanú lakossági közvélemény-kutatás eredményeinek elemzésére vállalkozik. A tanulmány arra a kérdésre keresi a választ, hogy milyen a biztosítók megítélése ügyfeleik körében, illetve az ügyfélélmény mely elemei határozzák meg leginkább a biztosítótársaságokkal való elégedettséget és elköteleződést.

\section{Adatok és módszer}

Az adatok a Századvég Alapítvány által a MABISZ megrendelésére készült vegyes kvantitatív és kvalitatív - módszertanú közvélemény-kutatásból származnak. 2019. május 1. és május 16. között készült egy 800 fős, a felnőttkorú magyar lakosságra nem, kor, iskolai végzettség és településtípus mentén reprezentatív kérdőíves kutatás telefonos kérdezési módszerrel (CATI). A mintavételből fakadó hibákat iteratív súlyozás segítségével korrigáltuk. A mintavételi módszerből fakadóan 95 százalékos valószínűséggel az elemzésben közölt adatok legfeljebb $+/-3,1$ százalékponttal térnek el attól az eredménytől, amit az ország összes felnőtt lakosának megkérdezése eredményezett volna.

Készült emellett egy kvalitatív irányú vizsgálat, mely 4 fókuszcsoportban zajlott. Két csoport volt Budapesten, egy Veszprémben és egy Kisvárdán. A résztvevők mindegyike rendelkezett biztosítással, vegyesen vettek részt csak lakásbiztosítással, illetve életbiztosítással rendelkező (tudatosabbnak vélt) ügyfelek. A csoportok nyolcfősek voltak, és a beszélgetések átlagosan 90 percig tartottak. Mindkét vizsgálat témája a biztosítótársaságokkal kapcsolatos érzések, attitűdök feltérképezése volt.

\section{Eredmények}

\section{Elégedettség, elkötelezettség}

A kutatásban a válaszadóktól azt kértük, hogy gondoljanak arra a biztosítójukra, amellyel a leggyakrabban kerülnek kapcsolatba. Így általános képet kaptunk a biztosítási piacról, de biztosítástípus vagy biztosító szerint nem tudtunk differenciálni. Az ügyfélelégedettséget a CSAT-tal (Customer Satisfaction Score) mértük (1. ábra). Az ügyfélelégedettség kifejezetten magas a magyar biztosítási piacon (az ötös skála átlaga 4,13). Viszonyításképpen ez az érték a bankoknál 4,09, míg egyes nem pénzügyi szereplőknél magasabb - a háziorvosoknál 4,34, az autószerelőknél pedig 4,23. Az eredmények megerősítik a MABISZ által közölt Biztosítási Bizalmi Index (BIBIX) és más, elégedettséget tükröző indexek eredményeit. ${ }^{4}$

\section{1. ábra: Ügyfél-elégedettség (CSAT). „Mennyire elégedett Ön a...?”}

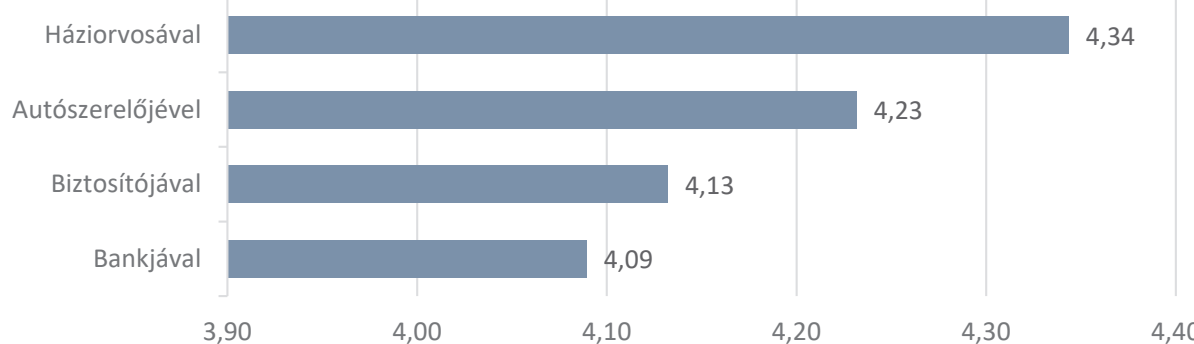

$N=800$

1-től 5-ig tartó skála releváns válaszainak átlagai (1=Egyáltalán nem elégedett, $5=$ Teljesen elégedett) Forrás: MABISZ-Századvég kutatás, 2019.

Az elkötelezettséget az NPS-Score-ral mértük (2. ábra). A biztosítók NPS-értéke a pozitív tartományban van $(4,6)$, vagyis többen vannak azok, akik ajánlanák saját biztosítójukat barátaiknak, kollégáiknak, mint azok, akik nem. Ez nagyjából megegyezik a Develor által 2017-ben mért értékkel (+7). ${ }^{5}$ Jelentősen elmarad ez az érték azonban a kutatásban szereplő többi szolgáltatóétól. 
2. ábra: NPS-értékek pénzügyi és nem pénzügyi szereplőknél (százalék)

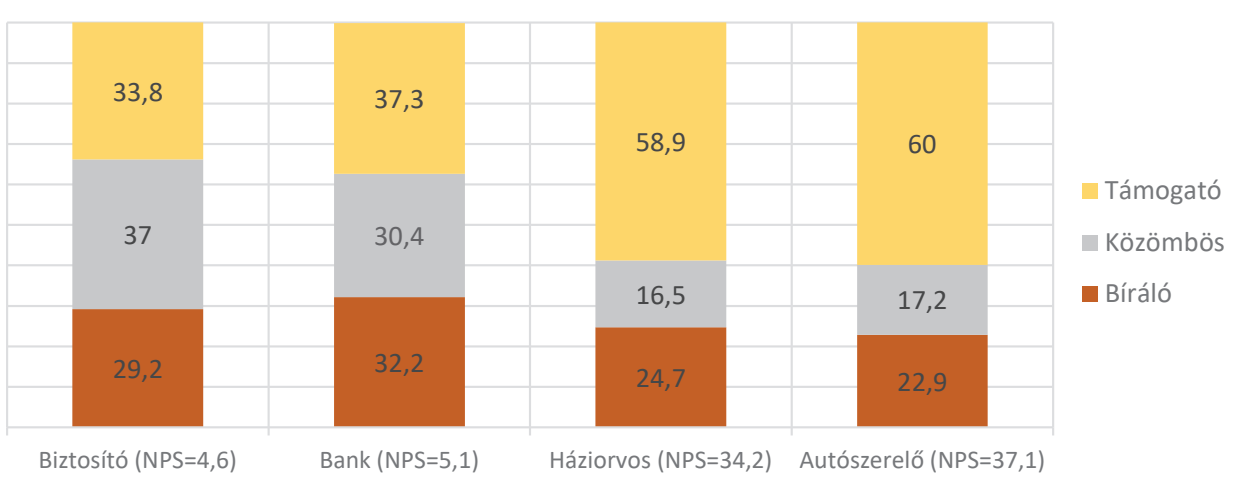

$N=800$

Forrás: MABISZ-Századvég kutatás, 2019.

A fókuszcsoportok eredményei segítenek megérteni azt, hogy vajon miért párosul a nagyon magas elégedettség mérsékeltebb ajánlási értékkel, és miért magasabbak ezek az értékek a nem pénzügyi szereplőknél.

„Mivel igazából nem gázoltak el, nem löttek le, nem zuhantam le, és nincs dolgom velük, igy tökéletesen elégedett vagyok...de azért ez terhelés alatt derülne ki, hogy ez igy mennyire jó."

(fókuszcsoport résztvevője Veszprémben)

„Ez [a bizalom hiánya] adódik abból is, hogy a biztositóval sokkal kevesebb kapcsolatom van..."

(fókuszcsoport résztvevője Budapesten)

Sok ügyfél kifejezetten elégedett biztosítójával, de mivel kevés kapcsolata/élménye van vele, az elkötelezettsége nem olyan magas. Emiatt lehet az is, hogy a bankok ajánlási értéke valamivel magasabb, a háziorvosoké és az autószerelőké pedig jóval magasabb, hiszen ezekkel a szereplőkkel több élményünk, találkozásunk, ügyünk van.

A fókuszcsoportokban mindemellett kifejezetten pozitív asszociációkkal találkoztunk a biztosítók kapcsán, úgymint biztonság, család vagy védelem (3. ábra).
3. ábra: Asszociációk a „biztosító” szóra a fókuszcsoportokon

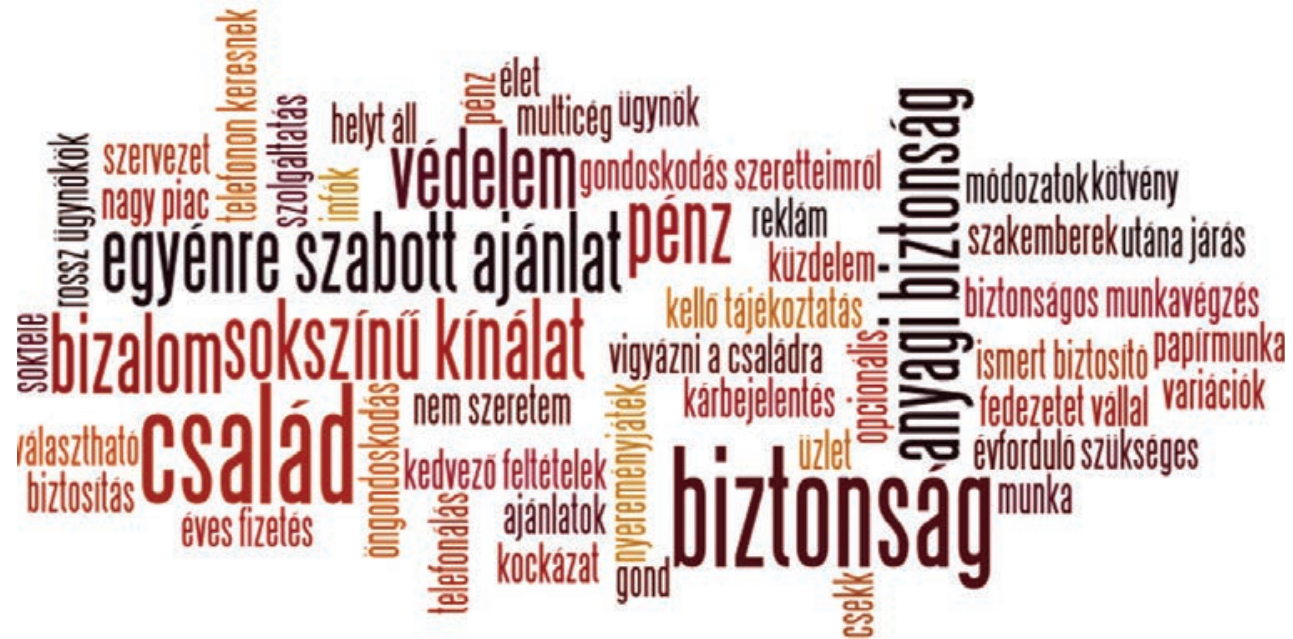

$N=32$

Forrás: MABISZ-Századvég kutatás, 2019.

Az elemzés arra is rámutatott, hogy a szocio-demográfiai változók nem magyarázzák sem az elégedettséget, sem az elköteleződést, azaz a különböző társadalmi csoportok egységesen elégedettek biztosítójukkal. Annak sincs szignifikáns hatása, hogy volt-e az elmúlt években káreseménye az ügyfeleknek - azaz a káreseményt megélt ügyfelek elégedettsége azonos azokéval, akiknek nem volt káreseményük az elmúlt években. A biztosítások számának ellenben látható a hatása: minél több biztosítással rendelkezik egy ügyfél, annál elégedettebb és elkötelezettebb.

\section{Ügyfélélmény a biztositóknál}

Fontosság

A kvantitatív kutatásban igyekeztünk megragadni az ügyfélélmény komplexitását, és annak négy dimenzióját vizsgáltuk (szolgáltatás; dolgozók; kommunikáció/elérhetőség; ügyfélkapcsolat). A négy dimenzió elemeit külön-külön értékelték a válaszadók aszerint, hogy mennyire fontos az az elem számukra, és mennyire elégedettek vele (1. táblázat). 


\section{1. táblázat: A ügyfélélmény négy vizsgált dimenziója}

\begin{tabular}{|c|c|c|c|}
\hline Szolgáltatás & Dolgozók & $\begin{array}{c}\text { Kommunikáció, } \\
\text { elérhetöség }\end{array}$ & Ügyfélkapcsolat \\
\hline $\begin{array}{c}\text { Jó ár-érték arányú } \\
\text { szolgáltatásokat nyújtanak }\end{array}$ & $\begin{array}{c}\text { Dolgozóik öszinték, } \\
\text { az igazat mondják }\end{array}$ & $\begin{array}{c}\text { Érthetően } \\
\text { kommunikálnak }\end{array}$ & $\begin{array}{c}\text { Az ügyfeleiket } \\
\text { helyezik az első helyre }\end{array}$ \\
\hline $\begin{array}{c}\text { Jó minőségü szolgáltatásokat } \\
\text { nyújtanak a kárrendezés során }\end{array}$ & $\begin{array}{c}\text { Dolgozóik } \\
\text { segítókészek }\end{array}$ & $\begin{array}{c}\text { Könnyen és gyorsan lehet } \\
\text { velük kapcsolatba lépni }\end{array}$ & $\begin{array}{c}\text { Megértik az } \\
\text { igényeimet }\end{array}$ \\
\hline $\begin{array}{c}\text { Jó minőségü szolgáltatásokat } \\
\text { nyújtanak általában (tehát nem a } \\
\text { kárrendezés, hanem a szerződéske- } \\
\text { zelés, kapcsolattartás során) }\end{array}$ & $\begin{array}{c}\text { Jók a digitális felületeik } \\
\text { (honlapok, alkalmazások) }\end{array}$ & $\begin{array}{c}\text { Megbecsülik a } \\
\text { hüségemet }\end{array}$ \\
\hline $\begin{array}{c}\text { Gyorsan és könnyen } \\
\text { elintézik az ügyeket }\end{array}$ & $\begin{array}{c}\text { Korszerủ digitális } \\
\text { szolgáltatást nyújt }\end{array}$ & \\
\hline Megbízhatóan szolgáltatnak & & & \\
\hline $\begin{array}{c}\text { Szolgáltatásaik a saját igényeimre } \\
\text { szabhatók }\end{array}$ & & & \\
\hline
\end{tabular}

\section{Forrás: MABISZ-Századvég kutatás, 2019}

A 4. ábrán látható, hogy az ügyfélélmény legfontosabb elemei a biztosítók esetén a szolgáltatáshoz, a dolgozókhoz és a klasszikus kommunikációs interakciókhoz kötődnek. A szolgáltatás megbizhatósága, ár-érték aránya és minősége a kárrendezés során, továbbá a dolgozók őszintesége és segitőkészsége, valamint az érthető kommunikáció a legfontosabbak egy biztosító ügyfele számára. Érdekes, hogy viszonylag kevésbé tűnik fontosnak, hogy a biztosítók megbecsüljék az ügyfél hüségét, vagy az, hogy jól reagáljanak egyedi igényekre, és talán a legmeglepőbb, hogy a digitális felületek és szolgáltatások az ügyfélélmény legkevésbé releváns elemei.
4. ábra: Kinyilvánított fontosság: „Az Ön számára mennyire fontosak az alábbiak az Ön biztosítójával kapcsolatban?”

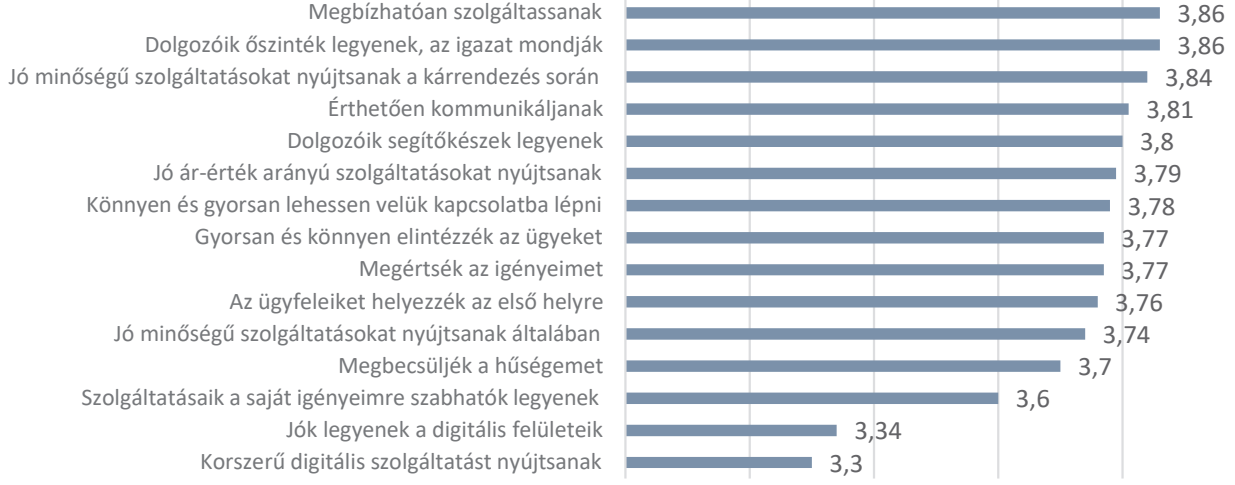

$N=517$

1-tól 4-ig tartó skála releváns válaszainak átlagai (1=Egyáltalán nem, 4=Nagyon fontos) Forrás: MABISZ-Századvég kutatás, 2019.

A válaszadók által kinyilvánított fontosság mellett származtatott fontosságot is számoltunk (5. ábra). A származtatott fontosság előnye, hogy előtérbe hozhatja a kevésbé tudatos, ám az elégedettségi adatok alapján fontos elemeket. A származtatott fontosságot úgy határoztuk meg, hogy egy lineáris regressziót futtattunk, amelyben a teljes elégedettség volt a függő változó, az egyes ügyfélélmény-elemekkel való elégedettségek pedig a független változók. A származatott fontosság indikátorai a standardizált béta együtthatók voltak. Első helyre kerül az egyéni igények megértése, ami a kinyilvánított fontossági listán még kilencedik volt. További tudatküszöb alatti tényezők a gyors és könnyü ügyintézés, valamint a hüség megbecsülése. Erősen „túlértékelt” tényező az elérhetőség - annak ellenére, hogy sokan spontán fontosnak tartják, alig van hatása az elégedettségre. ${ }^{6}$ Figyelemre méltó, hogy az egyébként igen árérzékeny magyar piacon, az ár-érték arány a túlértékelt kvadránsba került. A korszerü digitális szolgáltatások fontosabbak az elégedettség szempontjából, mint ahogy elsőre látszott, ám még így is csak a középmezőnyben helyezkedik el ez az elem. A származtatott fontosság vizsgálata tehát előtérbe hozta az ügyfélkapcsolat dimenzió egyes elemeit.

Összegzésképpen, egy biztosító ügyfelénél az ügyfélélmény kulcselemei a megbízhatóság, a segitókész dolgozók, az érthetö kommunikáció, a gyors, könnyü ügyintézés, a jó minőségü szolgáltatás és az ügyfelek igényeinek megértése. 


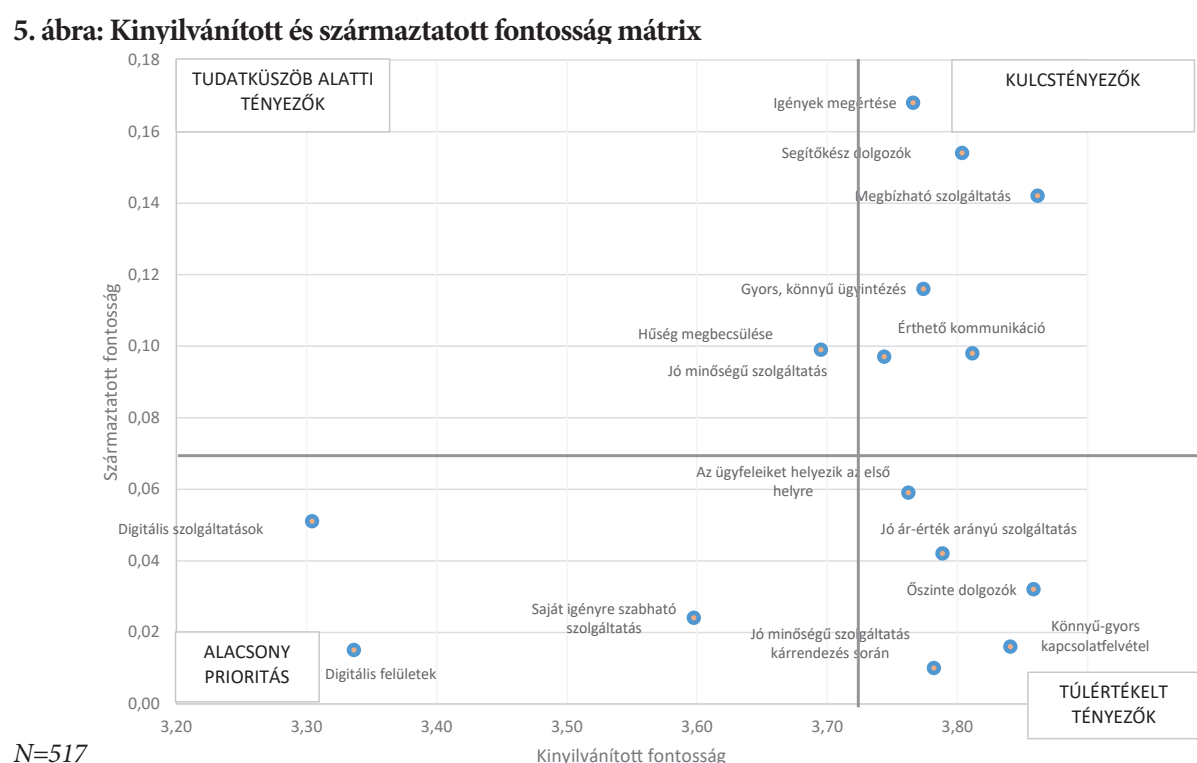

Forrás: MABISZ-Századvég kutatás, 2019.

A fókuszcsoportokon elhangzottak megerősítik a kvantitatív mérés eredményeit. Az ügyfeleknek fontos az érthetőség:

„A kisbetüs részek, amikre szokták mondani, hogy hát ezt hü, de el kell olvasni, az ne legyen mondjuk lehetöleg 10 oldal, mert ember a talpán, aki megjegyzi." (fókuszcsoport résztvevője Budapesten)

A segítőkészség, a kommunikáció és az egyéni igények megértése sokaknak a biztosítási ügynökökben manifesztálódik:

Szerintem nincs rossz biztositó, csak rossz üzletkötö, mert a biztositónak megvannak a feltételei, csak, ha az üzletkötö nem jól tájékoztat engem, akkor van az a csalódottság bennem, hogy a biztositó erre meg arra sem fizet." (fókuszcsoport résztvevöje Kisvárdán)

„Konkrétan az a fontos, hogy akinél megkötöm a biztositást, szimpatikus legyen, normális, elmagyarázzon mindent."

(fókuszcsoport résztvevöje Veszprémben)

Az említettekhez képest új elem a kvalitatív kutatások alapján, hogy a résztvevők nagyon gyakran említették a személyes kapcsolat fontosságát, és annak gyakori hiányát a pénzügyi szolgáltatóknál.
„Én például nagyon utálom ezeket az automatákat, tehát annyira személytelen, és sokkal több időbe kerül, hogy én felhívjam őket.

(fókuszcsoport résztvevője Budapesten)

„Szerintem kevésbé biznak az emberek, ha elmarad a személyes kapcsolat." (fókuszcsoport résztvevője Veszprémben)

\section{Elégedettség}

A fontosság-elégedettség mátrix alapján jó hír, hogy az ügyfelek számára fontos elemekhez magas elégedettség is társul (6. ábra). Relatíve fontos és relatíve alacsony az elégedettség (fejlesztendő terület) az ügyintézés gyorsasága, könnyüsége és az ügyfelek első helyre helyezése terén.

Készítettünk egy ún. GAP analízist (2. táblázat). Kiszámítottuk a fontosság átlaga és az elégedettség átlaga közötti differenciákat ügyfélélményelemenként. Amennyiben az elégedettség alacsonyabb, mint a fontosság (negatív érték), akkor az az ügyfélélményelem alulteljesít, amennyiben pozitív, úgy a terület túlteljesít. Látható, hogy a leginkább alulteljesítő elemek a hüség megbecsülése, az ügyfelek első helyre helyezése és a szolgáltatás minősége a kárrendezés során. Felülteljesítő területet lényegében nem találtunk, a digitális felületek, szolgáltatások helyzete a GAP-analízis alapján ideális (azonos fontosság és elégedettség érték).

6. ábra: Kinyilvánított és származtatott fontosság mátrix

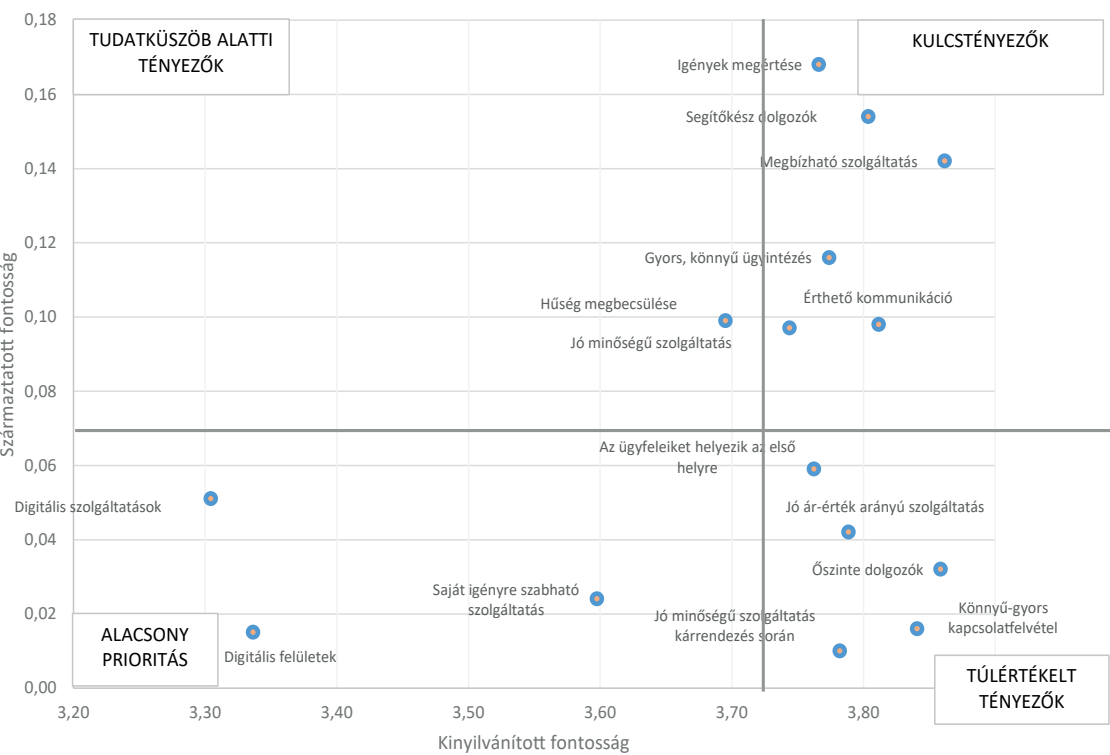

$N=517$

Forrás: MABISZ-Századvég kutatás, 2019. 
2. áblázat: GAP-analízis a fontossági és elégedettségi adatokra

\begin{tabular}{|c|c|c|c|}
\hline Ügyfélélményelem & Kinyilvánított fontosság & Elégedettség & Különbség \\
\hline Hüség megbecsülése & 3,70 & 3,19 & $-0,51$ \\
\hline Az ügyfeleiket helyezik az elsö helyre & 3,76 & 3,31 & $-0,45$ \\
\hline Jó minöségü szolgáltatás kárrendezés során & 3,84 & 3,39 & $-0,45$ \\
\hline Öszinte dolgozók & 3,86 & 3,44 & $-0,41$ \\
\hline Gyors, könnyü ügyintézés & 3,77 & 3,38 & $-0,40$ \\
\hline Jó ár-érték arányú szolgáltatás & 3,79 & 3,40 & $-0,39$ \\
\hline Megbizható szolgáltatás & 3,86 & 3,47 & $-0,39$ \\
\hline Könnyü-gyors kapcsolatfelvétel & 3,78 & 3,41 & $-0,37$ \\
\hline Igények megértése & 3,77 & 3,42 & $-0,35$ \\
\hline Érthető kommunikáció & 3,81 & 3,48 & $-0,33$ \\
\hline Saját igényre szabható szolgáltatás & 3,60 & 3,27 & $-0,33$ \\
\hline Jó minőségü szolgáltatás & 3,74 & 3,43 & $-0,31$ \\
\hline Segitökész dolgozók & 3,80 & 3,55 & $-0,25$ \\
\hline Digitális felületek & 3,34 & 3,36 & 0,02 \\
\hline Digitális szolgáltatások & 3,30 & 3,35 & 0,05 \\
\hline
\end{tabular}

$N=517$

1-töl 4-ig tartó skála releváns válaszainak átlagai (1=Egyáltalán nem, 4=Nagyon fontos)

Forrás: MABISZ-Századvég kutatás, 2019.

Bár láttuk, hogy az ügyfelek társadalmi háttértől függetlenül meglehetősen egységesek biztosítójuk megítélését tekintve, felmerülhet a kérdés: mindenkinek ugyanazt jelenti az ügyfélélmény? Megvizsgáltuk, hogy vajon a különböző szocio-demográfiai csoportok különböznek-e a tekintetben, hogy mely tényezők fontosak számukra egy biztosító ügyfeleként. Nem találtunk olyan változót, ami szignifikánsan elmozdította volna a fontosság-elégedettség mátrixot. Gyenge, de szignifikáns összefüggés látható az életkor és a digitális szolgáltatások fontossága között: valamivel fontosabb a negyven év alattiak számára, hogy egy biztosító korszerü digitális szolgáltatásokat nyújtson (7. ábra). Hangsúlyozzuk azonban, hogy a fiataloknál is az utolsó helyre került ez a két szempont.
7. ábra: A korszerủ digitális szolgáltatások fontossága életkor szerinti bontásban $(\mathrm{p}=\mathbf{0 , 0 5})$

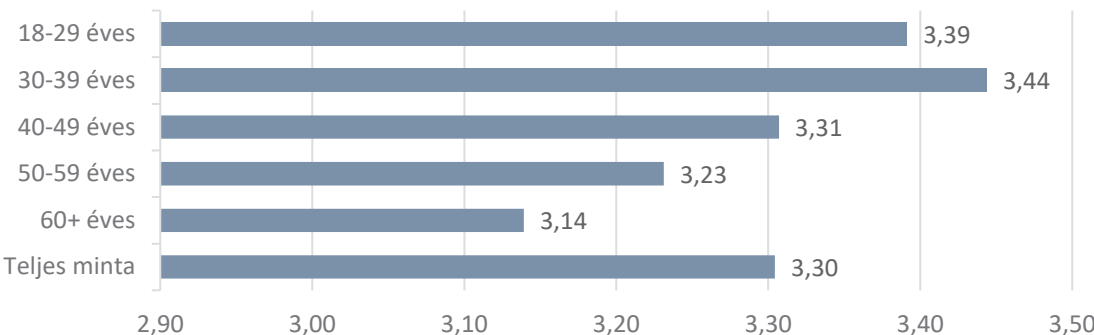

$N=506$

1-től 4-ig tartó skála releváns válaszainak átlagai (1=Egyáltalán nem, 4=Nagyon fontos)

Forrás: MABISZ-Századvég kutatás, 2019.

\section{Következtetések}

A tanulmány az ügyfélélmény pontosabb megértését tüzte ki célul a biztosítással rendelkező magyar lakosság körében. A felhasznált közvélemény-kutatási eredmények egyrészt rámutattak, hogy a biztosítási ügyfelek elégedettsége kifejezetten magas, bár más, nem-pénzügyi szereplőkétől elmarad. Emellett az elköteleződés - föleg az elégedettséghez képest - relatíve alacsony, igaz a pozitív tartományban van. Ez a tendencia nem feltétlenül negatív, a magyarázata pedig vélhetőleg a biztosítók mint szolgáltatók természetében keresendő. Egy lakásbiztosítóval jóval kevesebb interakciója és élménye van az ügyfeleknek, mint például egy bankkal, mobilszolgáltatóval vagy háziorvossal. Joggal feltételezhető, hogy kevésbé elkötelezett egy ügyfél azzal a szolgáltatóval, amelyikhez kevés élmény, érzelem köti. Az adatok arra is rámutattak, hogy minél több biztosítása (interakciója) van egy ügyfélnek, annál elkötelezettebb. A kvalitatív eredményekkel kiegészítve, a biztosítók imázsa a biztonság, védelem köréösszpontosul, az ügyfelek viszonya gyakran érzelemmentes, semleges, ami közepes bizalommal7 , közepes elköteleződéssel, viszont magas elégedettséggel párosul.

Az ügyfélélmény javítása során azokra az elemekre érdemes fókuszálni, melyek valódi hozzáadott értékkel bírnak.

Az ügyfélélmény alkotóelemeinek elemzése további fontos tanulságokkal szolgált. Kiderült, hogy egy biztosító kapcsán a legfontosabb, az ügyfélélményt leginkább javító elem az, ha a szolgáltató megbízható, a dolgozói segitőkészek, érthetően kommunikálnak, gyorsan és könnyen lehet náluk ügyet intézni, jó minőségű szolgáltatást nyúitanak, és értik az ügyfelek igényeit. Kevésbé fontos ugyanakkor egy biztosító kapcsán, hogy milyenek a digitális szolgáltatásai és felületei, 
vagyis a Capgemini előrejelzése a fogyasztók szintjén egyelőre nem jelentkezik. Ez a kép arra utal, hogy a biztosítókkal szemben támasztott elvárásaink különböznek más szolgáltatókétól. A KPMG és a Develor kutatásaival összehasonlítva a biztosítókhoz nagyobb valószínűséggel kapcsolunk konzervatívértékeket, és kevésbé támasztunk velük szemben innovatív elvárásokat.

A biztosítók számára legalább négy fontos dolog következik a kutatási eredményekből. Egyrészt az elköteleződés relatíve alacsony szintjének emelése az elsődleges stratégiai célok között kell, hogy legyen. Az elköteleződés javitása az ügyfélélmény javításán keresztül érhető el. Az eredmények azt sugallják, hogy az alacsony NPS-score a márka és az ügyfél közötti alacsony érzelmi kötelékkel és a kevés élménnyel függ össze, ezek fejlesztése tehát indokoltnak tünik. Az ügyfélélmény javítása során azokra az elemekre érdemes fókuszálni, melyek valódi hozzáadott értékkel bírnak. Láthattuk, hogy például a digitális fejlesztésektől - egyelőre legalábbis - jelentős eredményeket nem várhatunk. Másrészt, bár az üzleti világ minden területe a digitalizáció irányába halad, mind a kvantitatív, mind a kvalitatív adatok megerősítették, hogy az ügyfeleknek továbbra is fontos a személyes kapcsolat. Ez feltehetöleg összefügg az interakciók hiányának érzetével, így az ügyfélélmény javításának erre is tekintettel kell lennie. Harmadrészt a lojalitás erősítését kiemelt célként szükséges kezelni. Nem jó hír a biztosítók számára, hogy a GAPanalízis legrosszabb eredményét a hűség megbecsülése mutatja, ami fontos tudatalatti tényező. Negyedrészt a szolgáltatók alakíthatják is a fogyasztói igényeket. A korszerü digitális szolgáltatások és a személyre szabott szolgáltatások - szemben a nemzetközi trendekkel - Magyarországon nem kötődnek szorosan a ,jó biztosítóhoz" az ügyfelek fejében. Ennek oka lehet az is, hogy az ügyfelek nem ismerik a lehetőségeket. A modern szolgáltatások tudatosítása az ügyfélélmény új dimenzióit nyithatja meg a biztosítók számára.

\section{IRODALOMJEGYZÉK}

Capgemini (2019): World Insurtech Report 2019. Online

Tech-Report-2019/3aypnj/400831195?h=GQuvVO0BPd0C7jY49YjcrmgYoU cetöltés dátuma: 2019.10.31.

Develor (2016) : 3. Országos Ügyféélmény Kutatas. Online https://www.develor.hu/wp-content/uploads/2016/02/develor-cx-kutatas-

Johnston, R., - Kong, X. https://doi.org/10.1108/09604521111100225

KPMG (2018): The Anchor Moment Customer Experience Excellence Report. Online https://home.kpmg/content/dam/kpmg/hu/ pdf/KPMG 20-\%20The\%20Anchor\%20Moment.pdf Letöltés dátuma: 2019. 10.31.

80(6), p. p. 69-96.

https://doi.org/10.1509/jm.15.0420

\section{HIVATKOZÁSOK}

'Lásd például az alábbi 2016-os beszélgetést Pandurics Anett, a MABISZ elnöke és több hazai biztositótársaság vezetōje között a Portfolio Biztositás 2016 konferenciaján. https://piacesprofit.hu/gazdasag//szexinek-kell-lenni-meg-a-biztosionak-is/Letotés
dátuma: 2019. 10. 31 . 'Az NPS-score azegyik legelterjedtebb mérésie eszköze az ügyfél-elégedettségnek. A pozitivi érték azt jelenti, hogy az ügyfelek többsége
ajänlaná-e barátainak és ismerơseinek az adott szolgáltatást vagy szolgáltatót, mig a negativ értékek alacsony elkötelezettséget

${ }^{3}$ Forrás: http://www.biztositasiszemle.hu/cikk/hazaihirek/gazdasag/jobb_ugyfelelmeny_magasabb_elvarasok.7338.html "Lásd: https://mabisz.hu/merfoldkohoz-erkezett-a-biztositasi-szektor/ Letöoltés dátuma: 2019. 10. 3

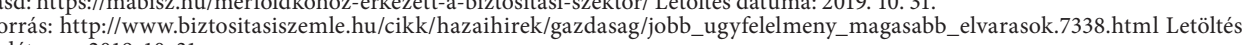
Ugyanez igaz a szolgáltatás minőséérére kárrendezés során, ami azonban elképzelhető, hogy azért mutat alacsony származtatott fontosságot, mert sok ügyfélnek nincs káreseménye. A dolgozók őszintesége szintén nem meghatározó az elégedettség szempontából, . dátuma: 2019.10.3 